\title{
FIBRE REINFORCED - FLY ASH, LIME SLUDGE STABILIZED CLAY SOIL AS SUBGRADE MATERIAL IN FLEXIBLE PAVEMENT
}

\author{
AYANI TASADUQ ${ }^{1} \&$ MOHD. IRSHAD MALIK ${ }^{2}$ \\ ${ }^{1}$ M.E Student Department of Civil Engineering, Chandigarh University, Gharuan, India \\ ${ }^{2}$ Assistant professor Department of Civil Engineering, Chandigarh University, Gharuan, India
}

Clay soil is an uncertain soil for construction due to its low value of strength and continuous swell shrink behavior. However, to make it appropriate for construction, it is required to be stabilized i.e. to increase its strength and other engineering properties, so that it becomes suitable for the construction of light as well as heavy structures. This stabilization is done by different solid wastes and natural and synthetic fibers, using different techniques. The useful effects of some easily seen solid wastes in addition to fiber reinforcement for stabilizing the clay soil has been considered in this paper. Throughout the study, fly ash in addition to lime sludge and polypropylene fiber has been used. The coal industry residue or flue ash used ranged from 10 to 40\%. The lime sludge used ranged in between $5 \%$ to $20 \%$. The polypropylene fiber used was $6 \mathrm{~mm}$ in length and ranging from 0.25 to $1 \%$. The inclusion rate of fly ash was 10, 20, 30, $40 \%$ and that of lime sludge was $5,10,15,20 \%$ and that of polypropylene was $0.25,0.5,0.75,1 \% .1$ The series of experiments conducted were standard proctor test, CBR and shear test. On the basis of results, flue ash and lime sludge enhanced the engineering properties of clay and polypropylene fiber acted as a reinforcement to fly ash, lime sludge stabilized soil. In addition to this, the disposal concerns of fly ash and lime sludge have also been taken into consideration. Utilization of solid wastes into construction also makes the project more economic. Thus, this study is believed to be beneficial from engineering, environmental and economical perspective.
\end{abstract}

KEYWORDS: Stabilization, Clay, Fly Ash, Lime Sludge, Polypropylene Fiber

Received: Jun 08, 2020; Accepted: Jun 28, 2020; Published: Oct 03, 2020; Paper Id.: IJMPERDJUN20201467

\section{INTRODUCTION}

Power services that utilize coal as their fuel yearly result in production of flue ash in indefinite quantity, as a residue and the natural throw away of this waste residue has become an expanding worry. Efforts have consistently been made by the scientists to utilize fly ash in pavement constructions in the areas which exists in the region of thermal power stations. Building materials that are rich in quality are not promptly obtainable in numerous areas as well as are expensive to move to faraway areas. Thus, in the course of the most recent couple of years, natural and financial issues have developed concerns to evolve alternate materials that can satisfy structure determinations.

The built-up procedures of stabilization of soil with flue ash and by including reinforcement in type of individual strands of fiber makes necessary improvement in building properties of soils/fly ash. Fibers are simply included as well as blended haphazardly with soil or flue ash.

The most appropriate encouraging methodologies right now is utilization of flue ash as a substitution to the clay soil in addition to fiber as support which shall take care of duo issues with the only effort which is the eradication of industrial residue concerns on one side of coin and supply of building materials that are rich in 
quality on the other side.

But in any case, the far-reaching effort is requisite to discern the impact of strands of polypropylene fiber on engineering behavior of soil-flue ash mix.

\subsection{Experimental Study}

The experimental investigation including mainly CBR and direct shear tests was conducted in order to look over the usability of flue ash into construction in addition to polypropylene acting as a support to soil. The flue ash was replaced by the soil as:

- fly ash only at an increment of $10 \%$, up to $40 \%$.

- Fly ash with lime sludge at an increment of $5 \%$, up to $20 \%$

- Fly ash with polypropylene fiber at an increment of $0.25 \%$, up to $1 \%$.

\subsection{Materials Used}

The earth material used in the current work is the clay which was brought amid the local areas of Chandigarh. The primary test conducted on the soil were for the consistency limits, in order to find the PI of the soil which determined the nature of the soil used. Following parameters were determined:

Liquid limit: 45

Plastic limit: 25.96

Plasticity index: 10.04

In addition to this, the other tests conducted on the soil were proctor test, California bearing ratio (CBR) and the shear test.

The parameters deduced from the above conducted tests are:

OMC: 16.0

MDD: $9.447 \mathrm{KN} / \mathrm{m} 2$

CBR soaked: 7.65

CBR un soaked: 2.63

Shear strength parameters $\varnothing$ and c: $44 \& 28$

The admixtures employed here are the fly ash and the polypropylene fiber. The flue ash being utilized in the study is class $\mathrm{C}$ flue ash. The polypropylene fiber added to the soil sustained with flue ash is $6 \mathrm{~mm}$ in length and acted as a reinforcement to it.

The compaction parameters for the given soil has been shown in fig 1: 


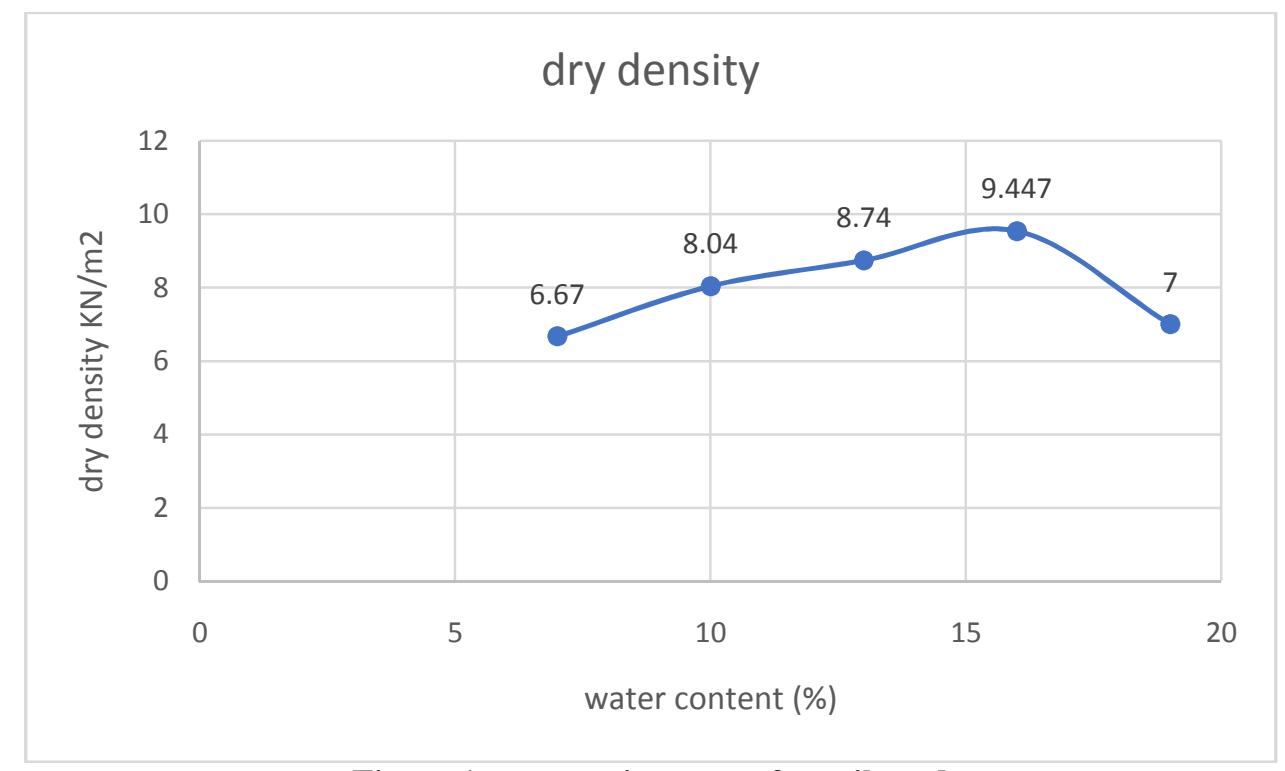

Figure 1: compaction curve for soil used

The compaction parameters for soil used, i.e. OMC and MDD determined were $16.5 \%$ and $9.54 \mathrm{KN} / \mathrm{m}^{2}$ respectively.

\subsection{Experimental program}

The tests conducted for this study were standard proctor tests, California bearing ratio and the shear test. All the experiments were conducted for different combinations of soil plus admixtures. The different combinations were:

- Stabilization with fly ash only

- Stabilization with fly ash and lime sludge

- Stabilization with fly ash plus lime sludge plus polypropylene fibre

The mixtures of soil plus flue ash, lime sludge and soil stabilized with flue ash, lime sludge plus polypropylene fibre for CBR and direct shear were processed following the OMC and MDD obtained from the standard proctor test. Inclusion rate for fly ash to the clay soil was $10,20,30,40 \%$. For lime sludge, the inclusion rate was 5, 10, 15, 20\% and that for polypropylene fibre was $0.25,0.5,0.75,1 \%$. All the experiments were conducted were in conformity with Indian standard specifications. The clay soil was mixed with fly ash initially and OMC was added to the mix. The inclusion rate of fly ash was $10 \%$, up to $40 \%$. Both CBR and direct shear were conducted on different mixes. The optimal percentage of flue ash $(20 \%)$ was determined corresponding to the maximum value of CBR and $\mathrm{c}$ and $\emptyset$. After the stabilization of soil with flue ash, lime sludge was added to it. The inclusion rate of lime sludge was $5 \%$ to $20 \%$. Again, both CBR and direct shear were conducted on different mixes. The favourable percentage of lime sludge corresponding to maximum value of CBR and c, $\varnothing$ value was $15 \%$. The soil plus flue ash plus lime sludge mixture was incorporated to polypropylene fibre strands. The inclusion rate of fibre was $0.25 \%$, up to $1 \%$. Again, CBR and direct shear were carried out on the samples. The optimum percentage of fibre was $0.5 \%$.

The results obtained for this study followed the similar trend of increment of CBR and shear strength as was seen while reviewing the literature conducted on stabilization of soil with fly ash and polypropylene fibre and some other solid wastes, agricultural wastes, natural and synthetic fibres by different researchers like by Fly ash and polypropylene fibre (Senol, 2011), polypropylene (Pal, 2015), polypropylene fibre (Teja, 2016), polypropylene fibre (Dixit, 2017), waste paper 
sludge ash (Khalid et.al., 2012), polypropylene fibre (Priya et. al., 2017), fly ash and polypropylene fibre (Kumar et. Al., 2019).

\section{RESULTS AND DISCUSSIONS}

A vast experimental study covering standard proctor test, CBR and direct shear test was conducted. The formulation used for the calculation of CBR is as follows:

$\mathrm{CBR}=\left(\mathrm{P}_{\mathrm{T}} / \mathrm{P}_{\mathrm{S}}\right) \times 100$

Where $\mathrm{P}_{\mathrm{T}}$ and $\mathrm{P}_{\mathrm{S}}$ represent load at $2.5 \mathrm{~mm}$ penetration and standard load respectively.

The formulation used for the calculation of direct shear test is as follows:

$\mathrm{S}=\mathrm{C}+\sigma \tan \varnothing$

Where S represents the shear strength, c corresponds to the cohesion of soil, $\varnothing$ corresponds to the angle of internal friction.

The effects of flue ash only and flue ash with the strands of polypropylene on CBR and shear strength of clay soil are to be studied respectively.

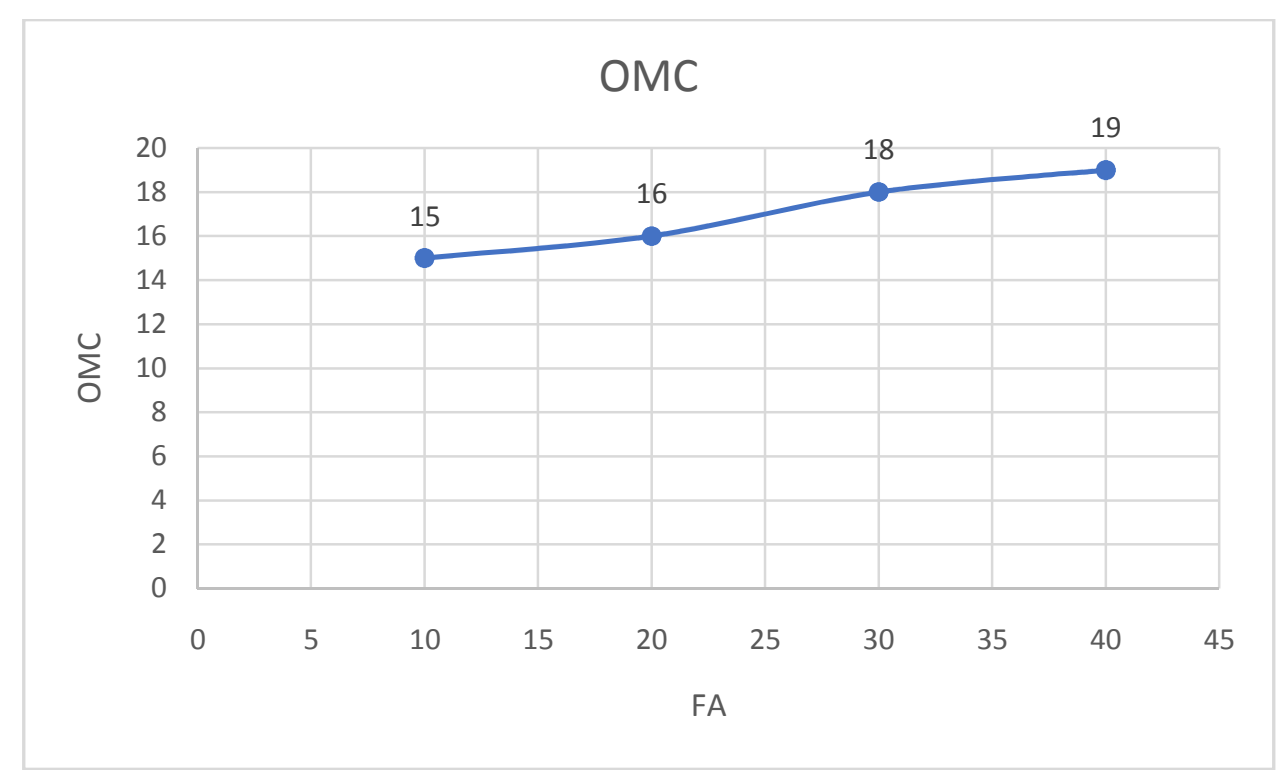

Figure 2: OMC varying with the rate of fly ash

Figure 2 gives the representation of trend of OMC on adding fly ash from 10 to $40 \%$ as a replacement of clay soil, at an increment of $10 \%$. On incorporating flue ash from 10 to $40 \%$ the OMC gets increased. The reason for this trend is because of the lack of arrangement of fly ash molecules. 


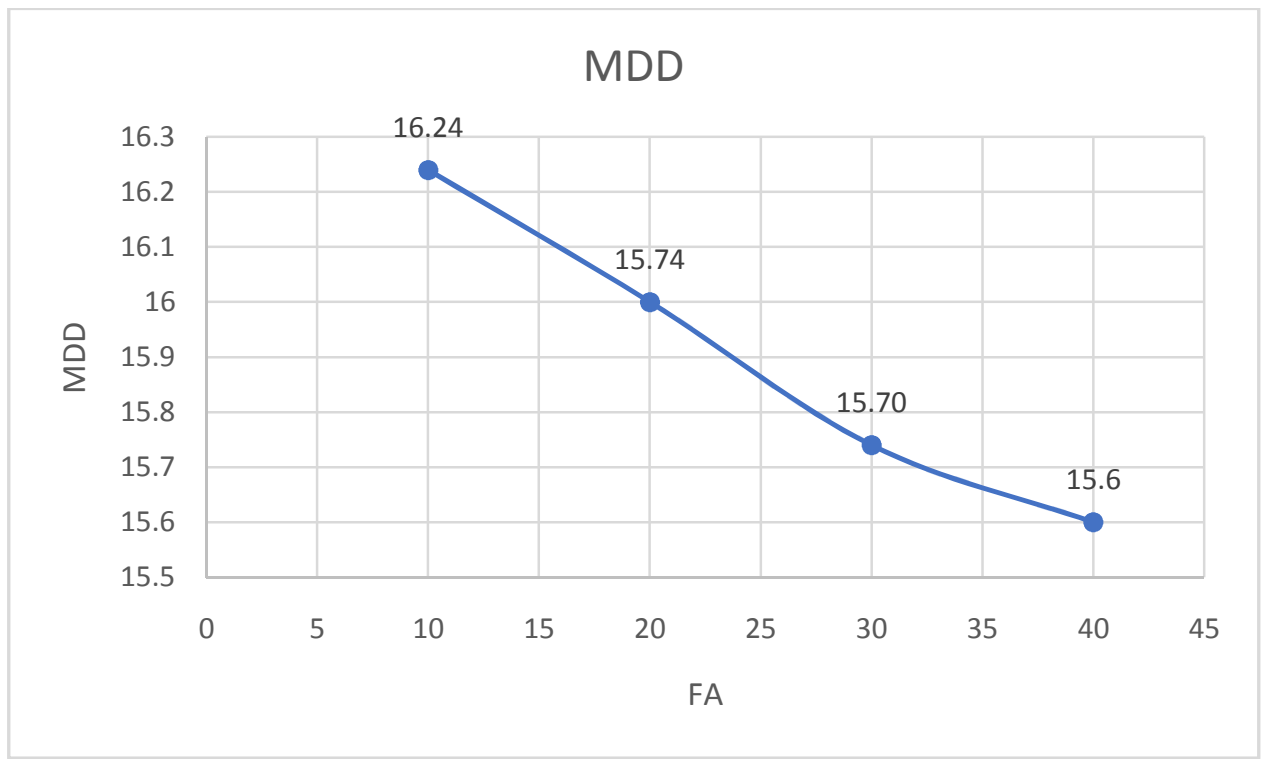

Figure 3: MDD varying with the rate of flue ash

Figure 3 provides the trend of MDD on addition of fly ash from 10 to $40 \%$ as a replacement of clay soil, at an increment of $10 \%$. On adding fly ash from 10 to $40 \%$, there is a continuous decrease in the MDD of the clay soil. This is due to the fact that the weight of fibre is less than that of soil particles at the same volume.

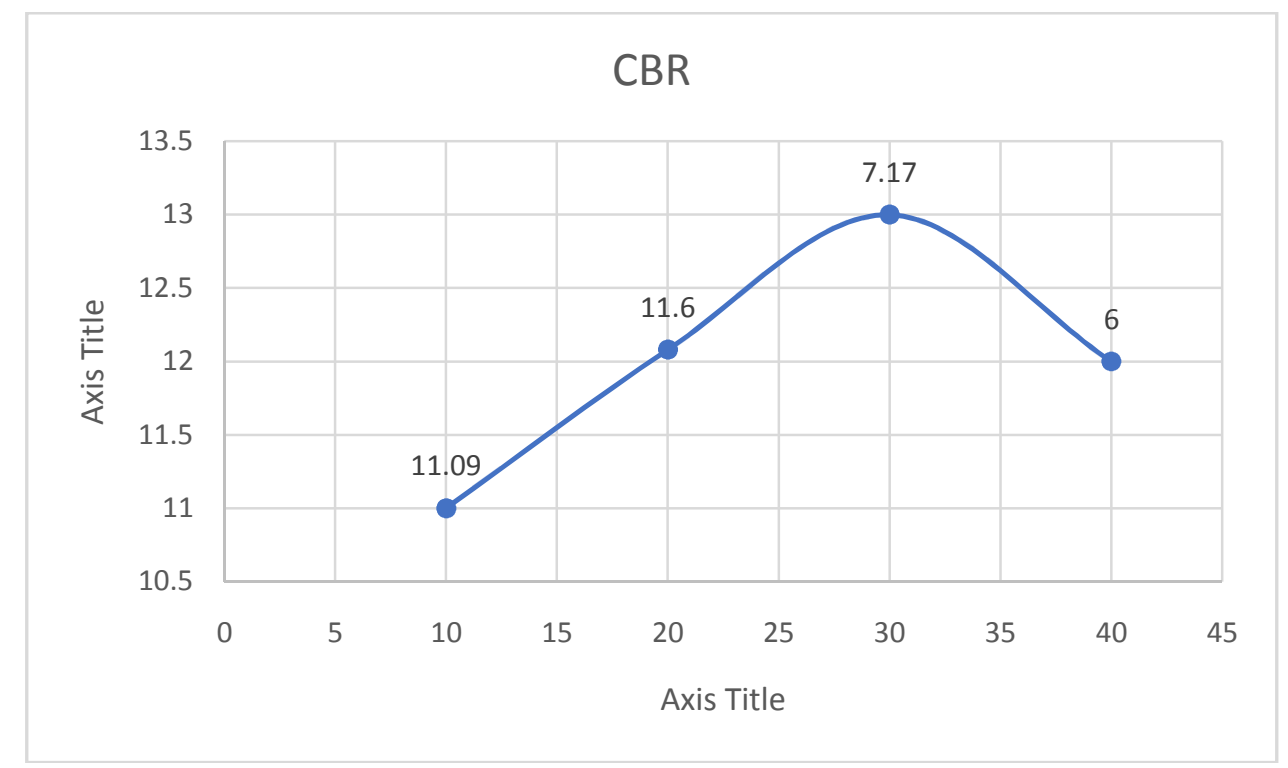

Figure 4: CBR varying with the rate of flue ash. 


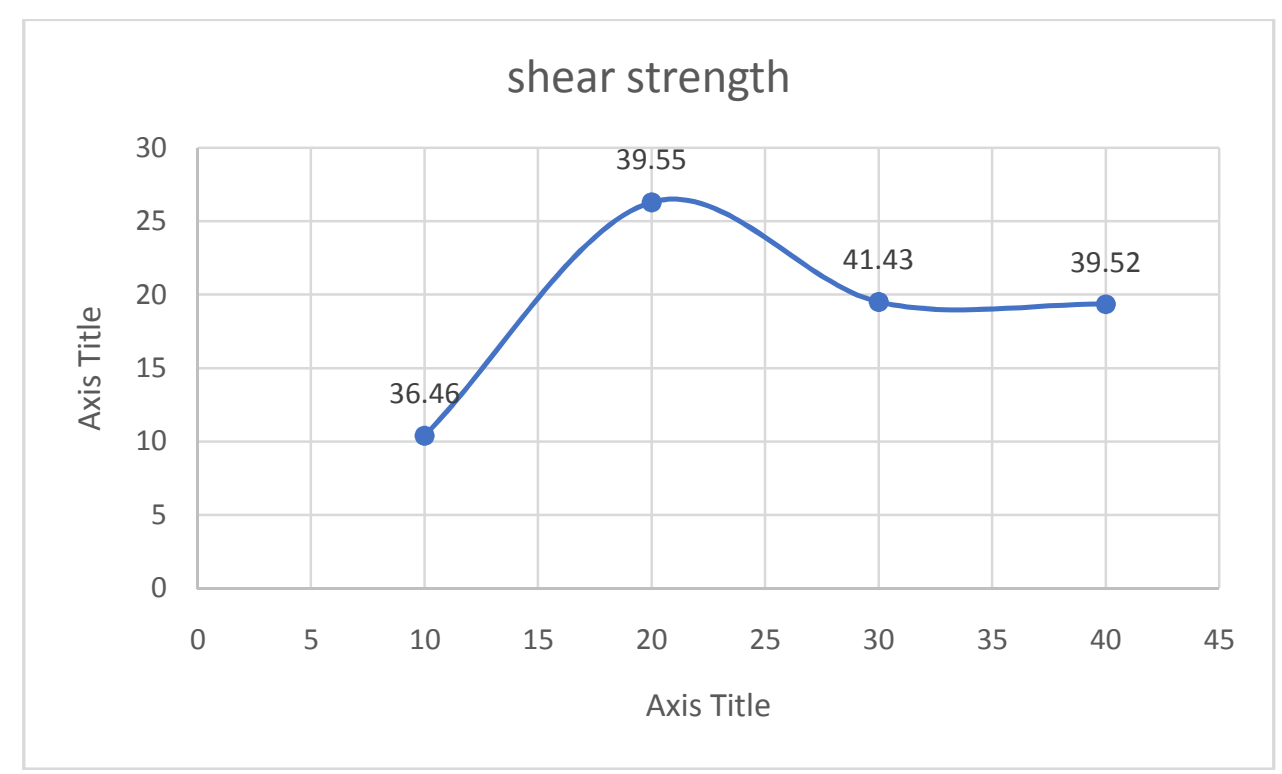

Figure 5: shear strength varying with the rate of fly ash.

Figure $4 \& 5$ show the trend followed by CBR and shear strength of soil on adding flue ash from 10-40\%, as a replacement of clay soil. The CBR value initially increases up to 13 on replacing soil with $30 \%$ of fly ash. Thereon the value got reduced when fly ash was added up to 40\%. Similar trend was followed by the shear strength also. The value initially got increased to $19.5 \mathrm{KN} / \mathrm{m} 2$, on adding fly ash from $10-30 \%$. thereon, the value got reduced to $18.8 \mathrm{KN} / \mathrm{m} 2$ on further addition of fly ash. This kind of behaviour is due to the reason that there is an increase in the angle of internal friction up to a certain limit of addition of fly ash, also known as the optimal value of flue ash which came out to be $30 \%$. Thereon, there is reduction in the cohesion of soil which leads to reduced CBR and shear strength.

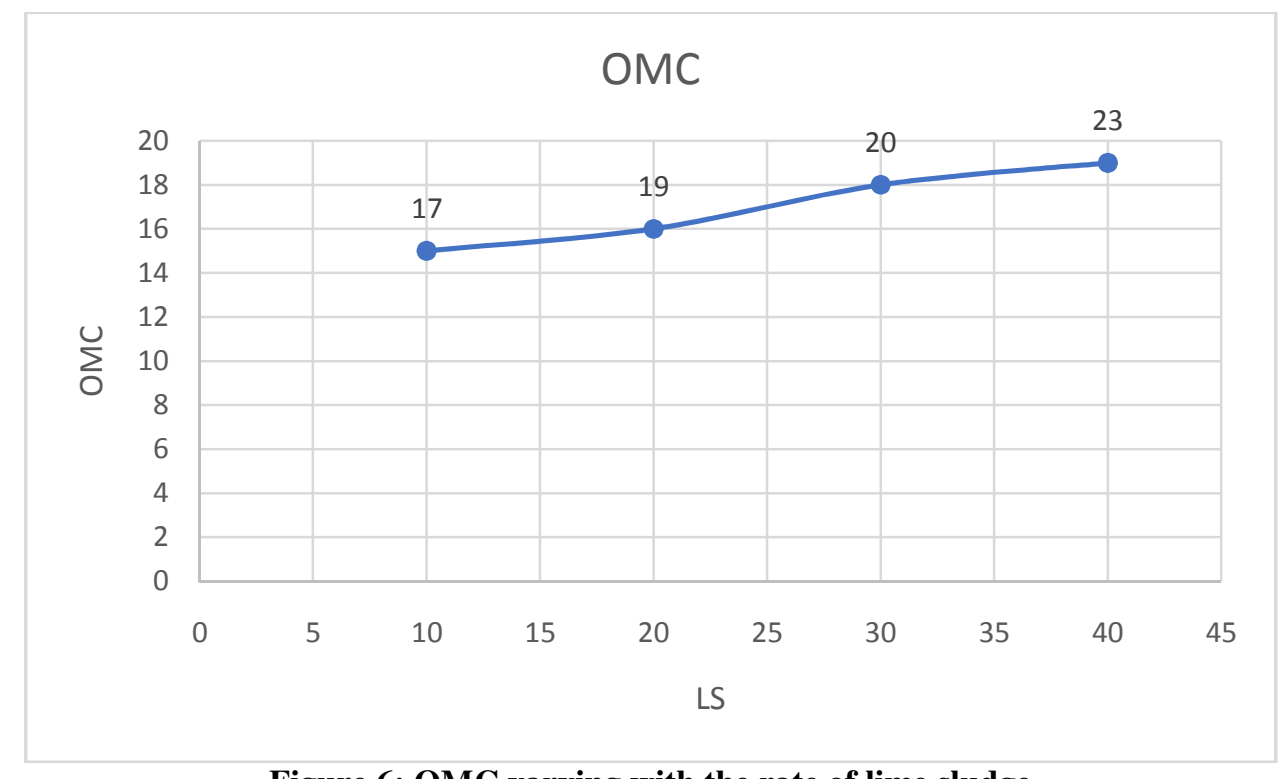

Figure 6: OMC varying with the rate of lime sludge

Figure 6 shows the variation of OMC on replacing the fly ash stabilized soil with the lime sludge 


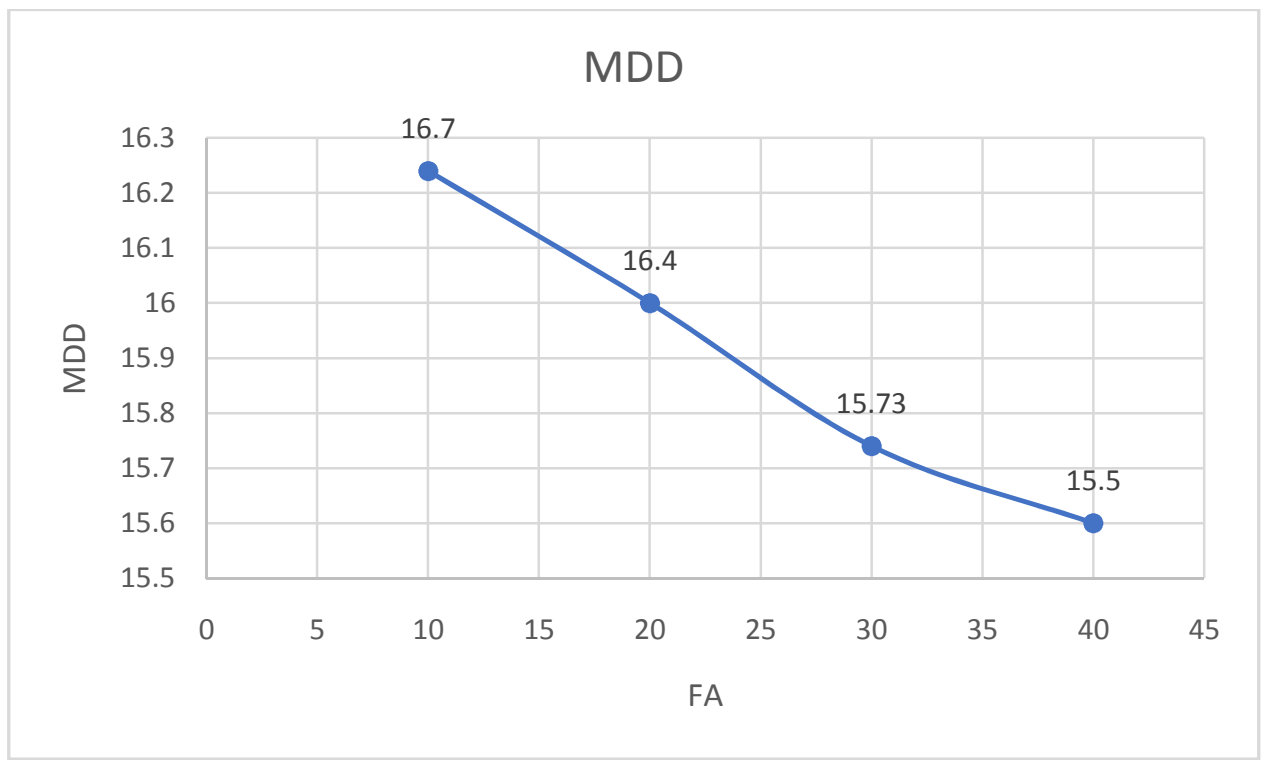

Figure 7: variation of MDD with the rate of lime sludge

Figure 7 represents the variation of MDD on adding lime sludge in different proportions to the soil stabilized with fly ash

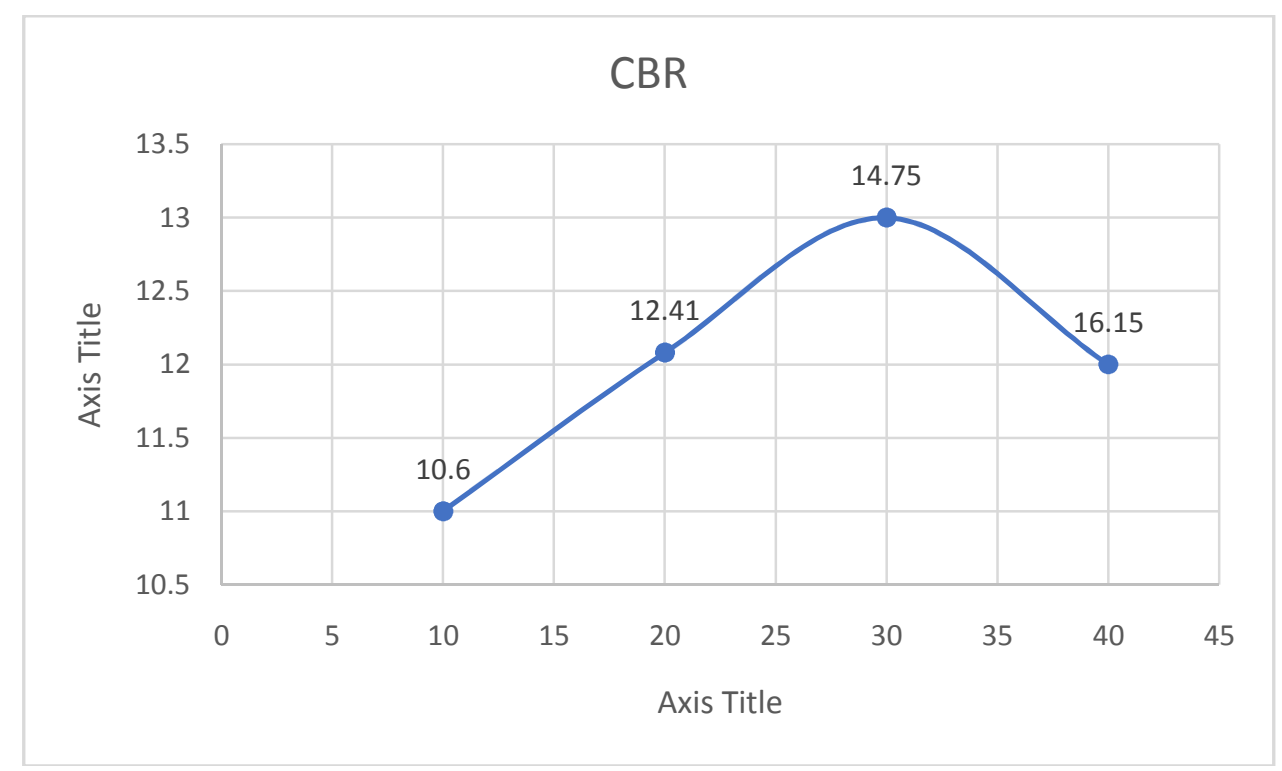

Figure 8: CBR varying with the rate of lime sludge 


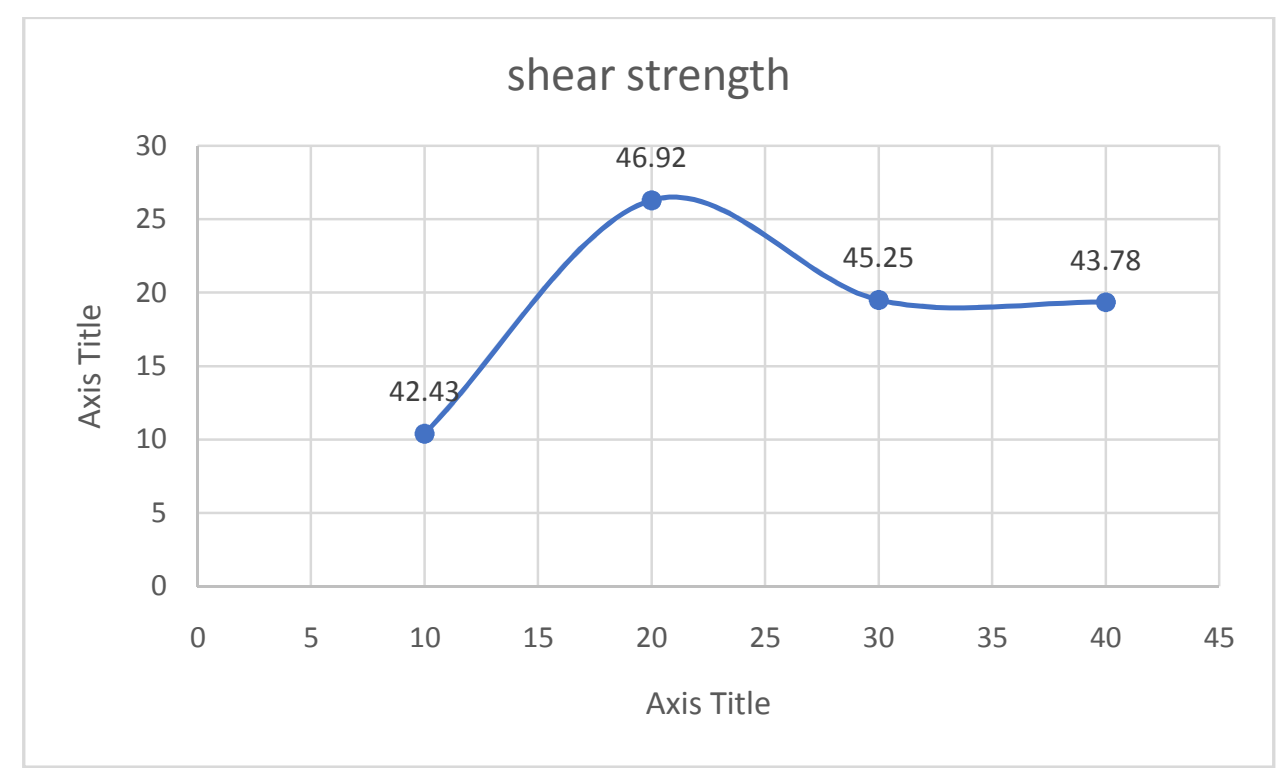

Figure 9: shear strength varying with the percentage of lime sludge

Figure $8 \& 9$ represent the variation of CBR and shear strength on adding lime sludge to the soil stabilized with the flue ash.

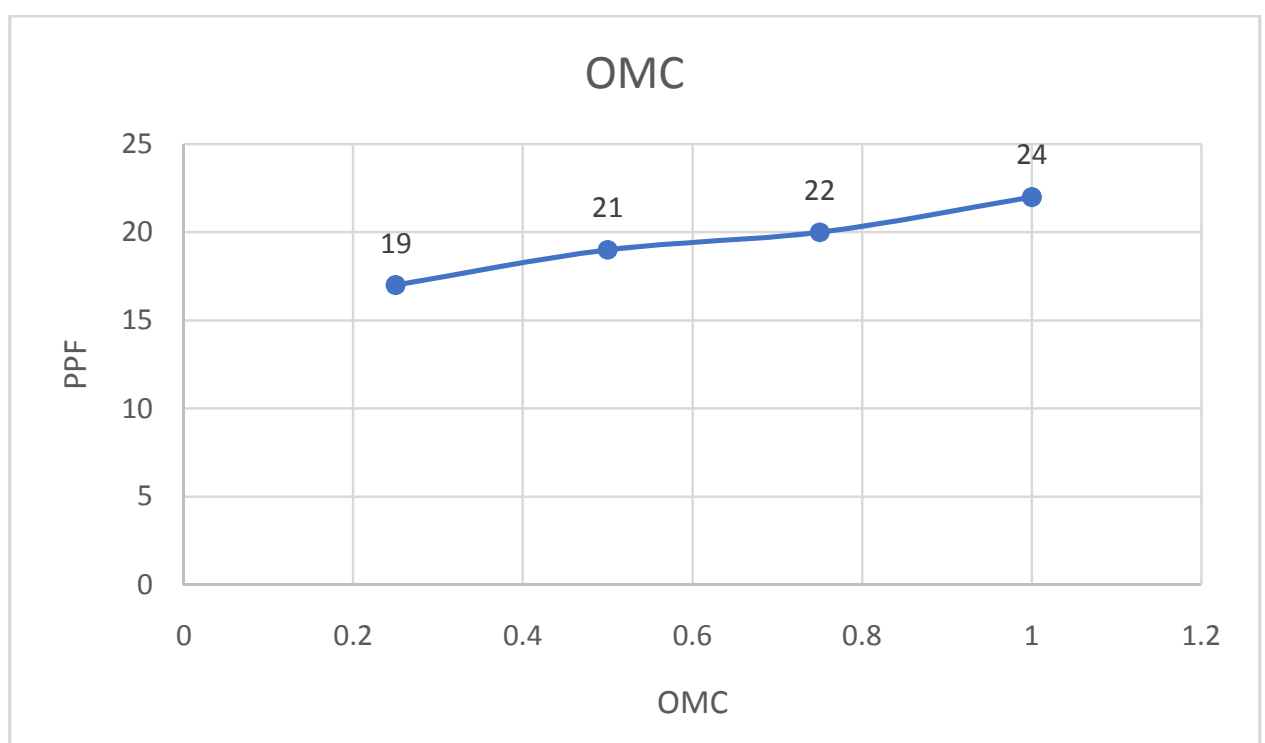

Figure 10: variation of $\mathrm{OMC}$ with the reinforcement of fibre to the clay stabilized with flue ash and lime sludge

Figure 10 shows the trend followed by OMC of soil on adding stands of polypropylene fibre to the flue ash plus lime sludge stable soil, as a replacement of clay soil. The length of polypropylene used was $6 \mathrm{~mm}$ and acts as a reinforcement to the soil. The OMC of the clay soil gradually increases to $24 \%$ from $19 \%$. The increase in OMC is because of the fact that the fibre can absorb more water than the clay. 


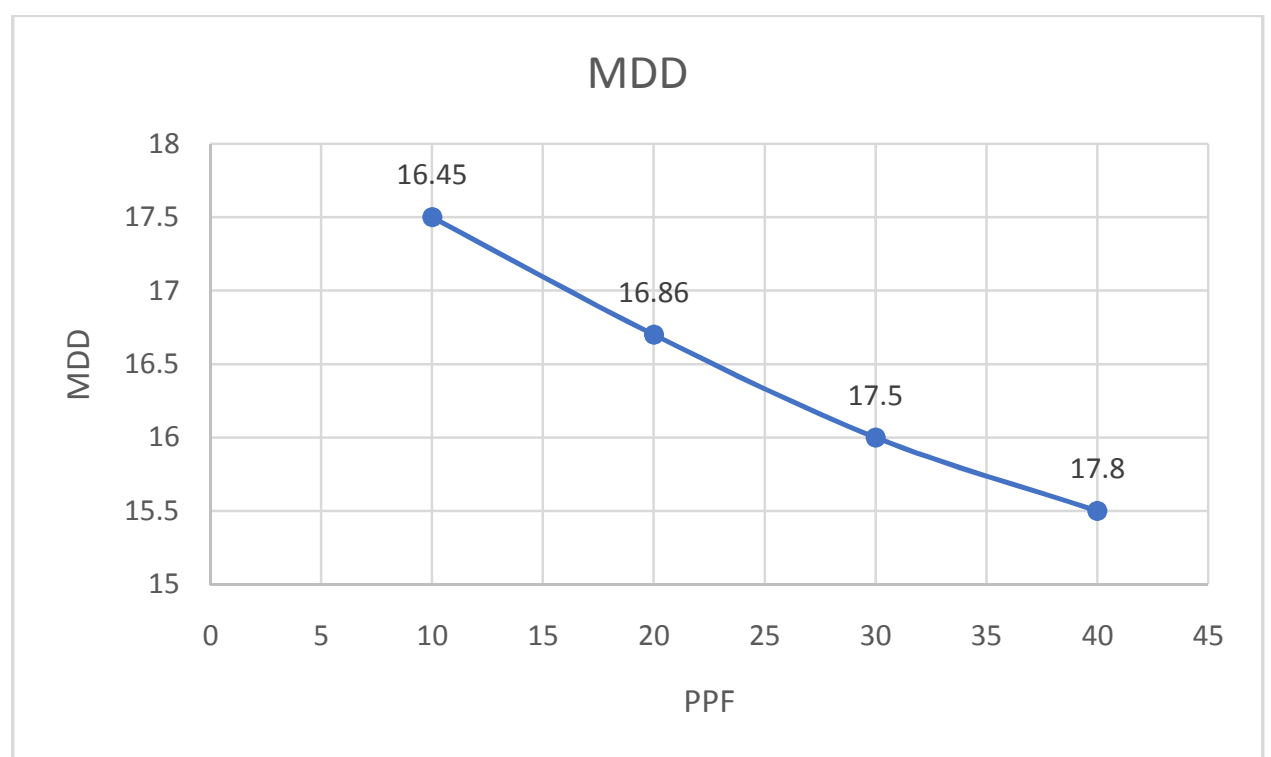

Figure 11: variation of MDD with the reinforcement of fibre to the clay stabilized with flue ash and lime sludge

Figure 11 shows the trend followed by MDD of soil on adding strands of polypropylene fibre to the flue ash, lime sludge stable soil, as a replacement of clay soil. The length of polypropylene used was $6 \mathrm{~mm}$ and acts as a reinforcement to the soil. The MDD of the clay soil gradually decreases to 16 from 13.75. This reduction of MDD is because of the reason that the increased moisture reduces the compaction effort of the clay.

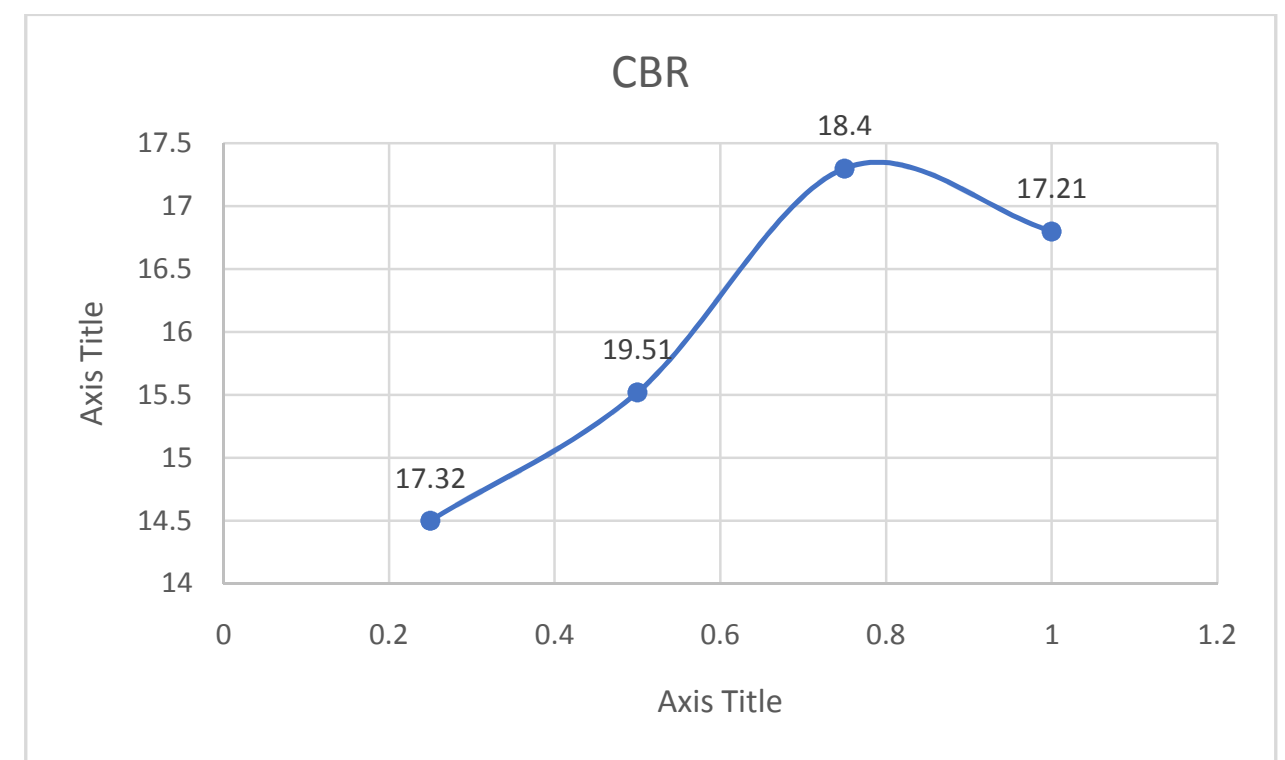

Figure 12: variation of CBR with the reinforcement of fibre to the soil stabilized with fly ash and lime sludge 


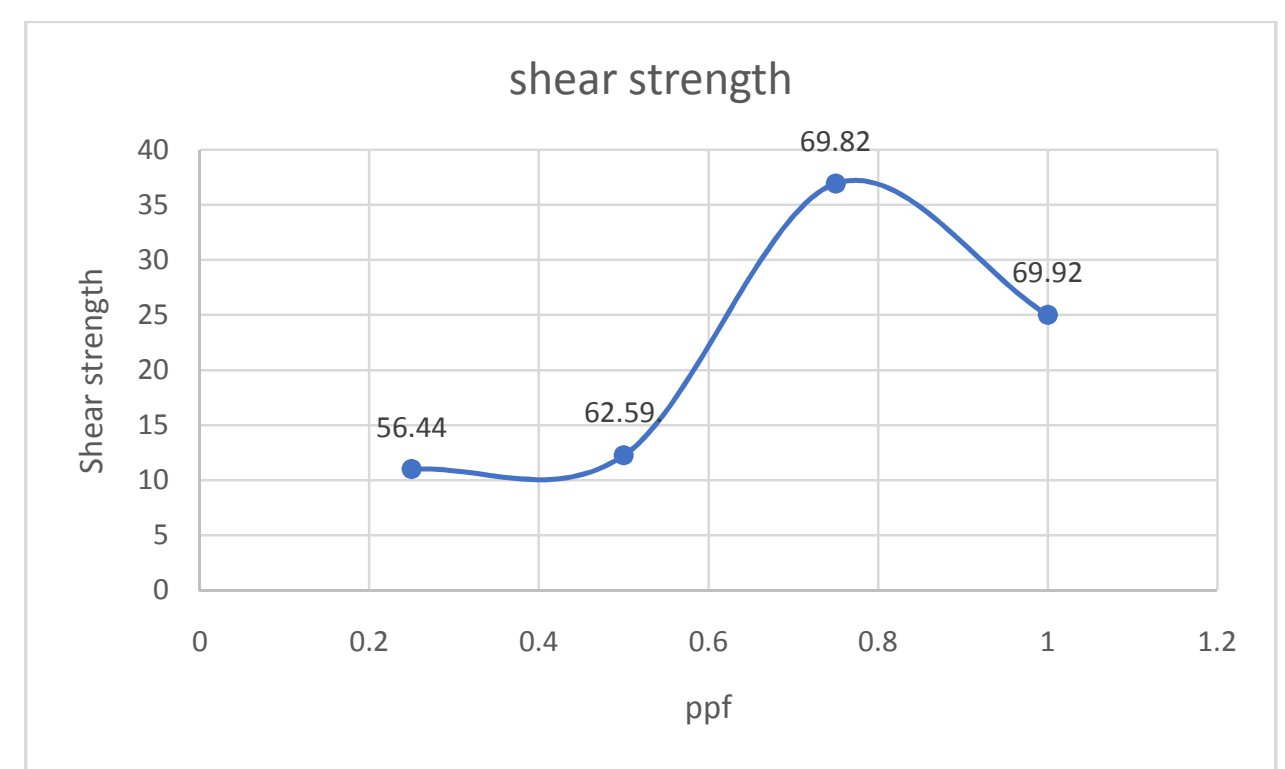

Figure 13: variation of shear strength with the reinforcement of fibre to the soil stabilized with fly ash and lime sludge

Figure $12 \& 13$ shows the trend followed by CBR and shear strength of soil on adding strands of polypropylene fibre to the flue ash and lime sludge stable soil, as a replacement of clay soil. The length of polypropylene used was $6 \mathrm{~mm}$ and acts as a reinforcement to the soil. The CBR value initially increases up to 17.3 on replacing soil with $0.75 \%$ of polypropylene fibre. Thereon the value got reduced when polypropylene was further added up to $1 \%$. Similar trend was followed by the shear strength also. The value initially got increased to $41.8 \mathrm{KN} / \mathrm{m} 2$, on addition of polypropylene fibre from $0.25 \%$ to $0.75 \% \%$. thereon, the value got reduced to $39 \mathrm{KN} / \mathrm{m} 2$ on further addition of polypropylene fibre. This is due to the fact that there is a mechanical bond developed between the fibre inclusions and the soil-flue ash mix because of which the strength gets increased. Further the binding between the soil stabilized with fly ash and that of fibre gets weakened which reduces the strength.

\section{CONCLUSIONS}

These are the conclusions made from the above investigation:

- $\quad$ OMC of the clay stabilized with the thermal plant residue i.e. flue ash goes on increasing on adding fly ash. The MDD of the soil-flue ash mix goes on decreasing with the addition of fly ash.

- Similar trend was followed while adding lime sludge to the soil stabilized with flue ash.

- The CBR value and the shear strength parameters c and $\varnothing$ also increase on adding flue ash up to $30 \%$. Further adding lime sludge up to the limit of $15 \%$, there was a hike in CBR and shear strength.

- On adding polypropylene fibre up to $0.75 \%$ to the soil-flue ash- lime sludge mix the CBR and shear strength parameters $\mathrm{c}$ and $\varnothing$ got enhanced. Thereupon addition of fibre reduces the overall strength.

- The optimal ratio of clay soil: fly ash: lime sludge: polypropylene fibre is found to be 54.25:30:15:0.75.

\section{REFERENCES}

1. Jadhan D.P. \& Nagarnaik P.B., 2008, Influence of polypropylene fibers on engineering behaviour of soil fly ash mixture for road construction, electronic journal of geotechnical engineering, vol. 13. 
2. Brooks M. R., 2009, soil stabilization with fly ash and rice husk ash, international journal of research and review applied science, Vol 01, Issue 03

3. Senol A., 2011, Effect of fly ash and polypropylene fiber content on the soft soil, Bulletin of Engineering Geology and Environment.

4. Bose B., 2012, Geo engineering properties of expansive soil stabilized with fly ash, electronic journal of geotechnical engineering, vol. 17, pp 1339-1353.

5. Khalid N., Mukri M., Faizan K., Arshad M.D, 2012, Clay soil stabilized using WPSA mixtures, Electronic Journal of Geotechnical Engineering, Vol 17, pp 1215-1225.

6. Gumuser C., Senol A., 2013, effect of fly ash and different length of polypropylene fiber content on the soft soil, international journal of civil engineering

7. Sabat A. \& Pradhan A., 2014, Fiber reinforced fly ash stabilized expansive soil mixes as subgrade material in flexible pavement, Electronic Journal of Geotechnical Engineering, Vol 19, pp 5757-5770.

8. Pal S., Sonthwal V.K., and Rattan J.S., 2015, review on stabilization of soil using polypropylene waste fiber material, International Journal of Innovative Research in Science, Engineering and Technology, Vol 04, Issue 11.

9. Teja M.S., 2016, Soil stabilization using polypropylene fiber materials, International Journal of Innovative Research in Science Engineering and Technology, Vol 05, Issue 09.

10. Dixit M.S., 2017, Optimum use of polypropylene fibers improves soil properties, International Khalid N., Mukri M., Faizan K., Arshad M.D, 2012, Clay soil stabilized using WPSA mixtures, Electronic Journal of Geotechnical Engineering, Vol 17, pp 1215-1225.

11. Priya C.M.S, Archana S., Albert A.B. and Dheeraj A.D., 2017, Stabilization of clayey soil using polypropylene fiber, International Journal of Engineering and Technology, Vol. 04, Issue 04.

12. Kumar R. and Goyal T., 2019, Increasing the strength of soil using fly ash and polypropylene fiber, International Research Journal of Engineering and Technology, Vol 06, Issue 05. 

